Огляди літератури, оригінальні дослідження, погляд на проблему, ювілеї

УДК 616.12-008.831.1-06:616.89-008.46

DOI 10.11603/1811-2471.2019.v0.i1.10063

\title{
ДОБОВИЙ ПРОФІЛЬ АРТЕРІАЛЬНОГО ТИСКУ ТА КОГНІТИВНІ ПОРУШЕННЯ
}

\author{
๑В. А. Скибчик', О. С. Пелешко² \\ Львівський національний медичний університет імені Данила Галицького ${ }^{1}$ \\ КП «Центральна міська лікарня Червоноградської міської ради»
}

PЕзЮМЕ. Взаємозв'язок між підвищеним артеріальним тиском (АТ) та когнітивними порушеннями (КП) привертає особливу увагу протягом останніх десятиліть. На сьогодні немає достатньо даних щодо впливу добового профілю АТ на когнітивні функції.

Мета - вивчити стан когнітивних функцій у хворих з гіпертонічною хворобою (ГХ) залежно від особливостей добового профілю АТ.

Матеріал і методи. О6стежено 45 хворих із ГX II-III стадій, 2-3 ступенів (середній систолічний та діастолічний

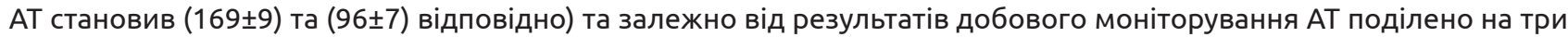
групи: перша група - dipper ( $n=20)$, друга - nondipper ( $n=14)$, третя - hyрег-dipper (n=11). Для вивчення когнітивних функцій застосовували коротку шкалу дослідження психічного статусу (MMSE).

Результати. Серед пацієнтів групи dipрег когнітивні порушення виявлено у 70 \% випадків, серед пацієнтів групи nondipper - у 93 \% випадків, у групі hурег-diррег когнітивні розлади спостерігали в 100 \% випадків. У структурі когнітивних порушень серед пацієнтів групи dipper та nondippeг переважали легкі когнітивні порушення, тоді як у групі hурег-dippeг частіше діагностували помірні когнітивні порушення. У пацієнтів һурег-diррег відзначали достовірно гірші показники когнітивних функцій за шкалою MMSE порівняно з пацієнтами dipper $((25,9 \pm 1,3)$ та $(26,8 \pm 2,7)$ відповідно, р<0,05).

Висновки. Когнітивні порушення було виявлено у трьох групах хворих із ГХ, проте достовірно нижчі показники когнітивних функцій мали місце у хворих з надмірним нічним зниженням АT (hyper-dipper), також у них частіше виявляли помірні когнітивні порушення.

КЛЮчОВІ СлОВА: гіпертонічна хвороба; когнітивні порушення; добовий профіль артеріального тиску.

Вступ. Взаємозв'язок між високим артеріальним тиском (АТ) і розладами когнітивних функцій встановлено в багатьох дослідженнях [1, 2]. Наявність артеріальної гіпертензії в середньому віці асоційована з підвищеним ризиком розвитку когнітивних порушень (КП) у літньому і старечому віці $[3,4]$. Проте немає єдиної думки щодо впливу на когнітивну сферу добового профілю АT, peзультати досліджень щодо цього питання досить суперечливі $[5,6]$.

Мета дослідження - вивчити стан когнітивних функцій у хворих із гіпертонічною хворобою (ГХ) залежно від особливостей добового профілю АТ.

Матеріал і методи дослідження. Ми обстежили 45 пацієнтів (58 \% чоловіки) із ГХ І-ІІІ стадій, 2-3 ступенів (середній систолічний та діастолічний

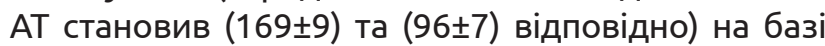
КП «ЦМЛ ЧМР». Усім пацієнтам проведено добове моніторування АТ; хворих поділено на три групи залежно від добового профілю АТ. Першу групу склали 20 хворих (середній вік - $(50,3 \pm 7,6)$ року) 3 профілем типу dipper (нічне зниження АТ на 10$20 \%$, тобто оптимальне). Другу групу склали 14 хворих (середній вік - $(48,3 \pm 11,0)$ року) з профілем типу nondipper (нічне зниження АТ 0-10\%, тобто недостатнє зниження АТ). Третю групу склали 11 хворих (середній вік - $(49,5 \pm 6,9)$ року) із профілем типу hyper-dipper (зниження АТ уночі більш ніж на $20 \%$, тобто надмірне зниження АТ). 3 метою оцінки когнітивних функцій пацієнтів використову- вали коротку шкалу дослідження психічного статуcy (Mini-Mental State Examination - MMSE), 2930 балів розцінювали як відсутність порушення когнітивних функцій, 27-28 балів - як легкі порушення, 24-26 балів - як помірні когнітивні порушення, 20-23 бали - як початкову стадію деменції, $<20$ балів - як виражену стадію деменції. Стійкість уваги та швидкість сенсомоторних реакцій оцінювали за допомогою таблиць Шульте. Отримані результати обробляли за допомогою програми «STATISTIKA FOR WINDOWS». Вірогідність різниці між середніми кількісними значенням двох вибірок визначали за критерієм Манна-Уїтні.

Результати й обговорення. При аналізі отриманих даних когнітивні розлади за шкалою MMSE діагностували у $70 \%$ ( $n=14)$ хворих групи dipper, у $93 \%(n=13)$ хворих групи nondipper та у $100 \%$ (n=11) хворих групи hyper-dipper. Найбільші труднощі у пацієнтів виникали при виконанні розділів: «Увага та рахунок», «Здатність до обліку», «Пам'ять», «Копіювання». У хворих із групи dipper та nondipper частіше діагностували легкі КП за шкалою MMSE (рис. 1). Достовірної різниці за середніми результатами MMSE між двома групами не виявлено (dipрег - $(26,8 \pm 2,7)$; nondippers - $(26,7 \pm 1,1), p>0,05)$. Водночас у групі hyper-dipper частіше діагностували помірні КП (рис. 1), середній показник цих пацієнтів за шкалою MMSE був достовірно нижчим, порівняно із середнім балом хворих групи dipper (hyper-dipper- $(25,9 \pm 1,3)$; dipper- $(26,8 \pm 2,7)$, $\mathrm{p}<0,05)$. 


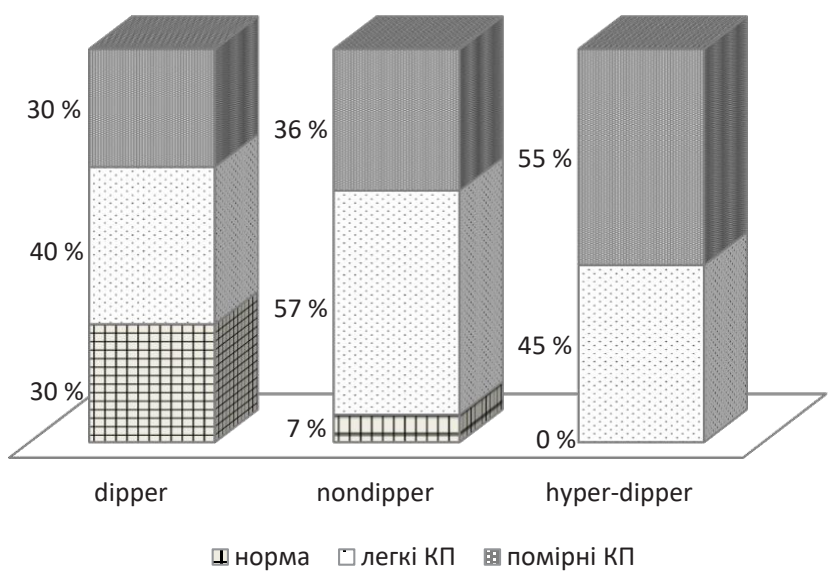

Рис. 1. Частота виявлення когнітивних порушень різного ступеня тяжкості у пацієнтів із гіпертонічною хворобою за шкалою MMSE.

Швидкість виконання завдань за таблицями Шульте перевищувала норму в усіх групах. Середній показник тестування у групі dipрег становив $(48,0 \pm 7,5)$ с, у групі nondipper час виконання завдання склав $(45,7 \pm 4,7)$ с, у групі hурег-dipper $(51,1 \pm 8,6)$ с. Хворі часто пропускали цифри, скаржились на неможливість зосередитись, швидку втому.

Висновки. 1. Когнітивні розлади за шкалою MMSE виявлено у 70 \% ( $n=14)$ хворих групи dipper, у 93 \% (n=13) хворих групи nondipper та у $100 \%$ (n=11) хворих групи hурег-dipper.

\section{ЛІТЕРАТУРА}

1. Cardiovascular risk factors and cognitive decline in middle-aged adults / D. Knopman, L. L. Boland, T. Mosley [et al.] / Atherosclerosis Risk in Communities (ARIC) Study Investigators // Neurology. - 2001. - No. 56 (1). P. 42-48.

2. Development of vascular risk factors over 15 years in relation to cognition: the Hoorn Study / Y. D. Reijmer, E. van den Berg, J. M. Dekker [et al.] // J. Am. Geriatr. Soc. 2012. - No. 60 (8). - P. 1426-1433.

3. Vascular risk factors and dementia: 40-year followup of a populationbased cohort / E. Ronnemaa, B. Zethelius, L. Lannfelt, L. Kilander // Dement. Geriatr. Cogn. Disord. - 2011. - No. 31 (6). - P. 460-466.

\section{REFERENCES}

1. Knopman, D., Boland, L.L., Mosley, T., Howard, G., Liao, D., Szklo, M., Mcgovern, P., \& Folsom, A.R. (2001). Cardiovascular risk factors and cognitive decline in middleaged adults. Atherosclerosis Risk in Communities (ARIC) Study Investigators. Neurology, 56(1), 42-48. DOI: https:// doi.org/10.1212/WNL.56.1.42

2. Reijmer, Y.D., van den Berg, E., Dekker, J.M., Nijpels, G., Stehouwer, C.D., Kappelle, L.J., \& Biessels, G.J. (2012). Development of vascular risk factors over 15 years
2. Взаємозв'язку між недостатнім нічним зниженням АТ та гіршим когнітивним статусом у пацієнтів із ГХ у проведеному дослідженні не виявлено. Як у хворих з групи dipper, так і у хворих $з$ групи nondipper діагностовано когнітивні порушення, частіше легкого ступеня.

3. Виявлено взаємозв'язок між надмірним зниженням АТ уночі та когнітивними розладами. У хворих з групи hyper-dipper частіше діагностували помірні КП, а середній бал за шкалою MMSE був достовірно нижчим, порівняно з хворими 3 групи dipper.

4. Киландер Л. Взаимосвязь артериальной гипертензии с когнитивными нарушениями: результаты 20-летнего наблюдения 999 пациентов / Л. Киландер, Н. Ниман, М. Боберг // Обзоры клинической кардиологии. - 2005. - № 2. - Р. 37-49.

5. Event_related brain potentials in elderly dippers and nondippers with recently diagnosed hypertension / P. Cicconetti, V. Ciotti, L. Tafaro [et al.] // Hypertens. Res. - 2004. No. 8. - P. 581-588.

6. Kanemaru A. The effects of short-term blood pressure variability and nighttime blood pressure levels on cognitive function / A. Kanemaru, K. Kanemaru, I. Kuwajma // Hypertens Res. - 2001. - No. 24. - P. 19-24.

in relation to cognition: the Hoorn Study. J. Am. Geriatr. Soc., 60 (8), 1426-1433.

3. Ronnemaa, E., Zethelius, B., Lannfelt, L., \& Kilander, L. (2011). Vascular risk factors and dementia: 40-year followup of a populationbased cohort. Dement. Geriatr. Cogn. Disord., 31 (6), 460-466.

4. Kilander, L., Niman, N., \& Boberg, M. (2005). Vzaimosvyaz arterialnoy gipertenzii s kognitivnymi narusheniyami: Rezultaty 20-letnego nablyudeniya 999 patsiyentov 
Огляди літератури, оригінальні дослідження, погляд на проблему, ювілеї

[Relationship of hypertension with cognitive impairment: Results of 20 years of follow-up of 999 patients]. Obzory klinicheskoy kardiologii - Clinical Cardiology Reviews, 2, 3749 [in Russian].

5. Cicconetti, P., Ciotti, V., Tafaro, L., Priami, C., Chiarotti, F., Costarella, M., ... \& Cacciafesta, M. (2004). Event_related

brain potentials in elderly dippers and nondippers with recently diagnosed hypertension. Hypertens. Res., 8, 581-588.

6. Kanemaru, A., Kanemaru, K., \& Kuwajma, I. (2001). The effects of short-term blood pressure variability and nighttime blood pressure levels on cognitive function. Hypertens. Res., 24, 19-24.

\title{
СУТОЧНЫЙ ПРОФИЛЬ АРТЕРИАЛЬНОГО ДАВЛЕНИЯ И КОГНИТИВНЫЕ НАРУШЕННЯ
}

\author{
๑В. А. Скибчик', О. С. Пелешко ${ }^{2}$ \\ Львовский национальный медицинский университет имени Данила Галицкого ${ }^{1}$ \\ КП «Центральная городская больница Червоноградского городского совета»
}

РЕзЮМЕ. Взаимосвязь между повышенным артериальным давлением (АД) и когнитивными нарушениями (КН) привлекает особое внимание в течение последних десятилетий. На сегодняшний день нет достаточно данных о влиянии суточного профиля АД на когнитивные функции.

Цель - изучить состояние когнитивных функций у больных с гипертонической болезнью (ГБ) в зависимости от особенностей суточного профиля АД.

Материал и методы. Обследовано 45 больных с ГБ ІІ-ІІІ стадий, 2-3 степеней (среднее систолическое и диа-

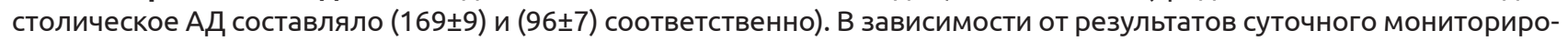
вания АД пациенты были разделены на три группы: первая - dipper ( $n=20)$, вторая - nondipper ( $n=14)$, третья - hyperdipper (n=11). Для изучения когнитивных функций применялась краткая шкала исследования психического статуса (MMSE).

Результаты. Среди пациентов группы diррег когнитивные нарушения выявлены в 70 \% случаев, у пациентов группы nondipper - в 93 \% случаев, в группе hyрег-dipper когнитивные расстройства наблюдались в 100 \% случаев. В структуре когнитивных нарушений у пациентов группы dipper и nondipper преобладали легкие когнитивные нарушения, тогда как в группе hyрег-dipрег чаще диагностировали умеренные когнитивные нарушения. У пациентов hyрег-dipрег наблюдались достоверно худшие показатели когнитивных функций по шкале MMSE по сPавнению с пациентами diррег $((25,9 \pm 1,3)$ и $(26,8 \pm 2,7)$ соответственно, $p<0,05)$.

Выводы. Когнитивные нарушения были выявлены в трех группах больных с ГБ, однако достоверно более низкие показатели когнитивных функций наблюдались у больных с избыточным ночным снижением АД (hурегdipрег), также у них чаще обнаруживали умеренные когнитивные нарушения.

КЛючЕВЫЕ СЛОВА: гипертоническая болезнь; когнитивные нарушения; суточный профиль артериального давления.

\section{DAILY PROFILE OF ARTERIAL PRESSURE AND COGNITIVE DISTURBANCE}

\author{
OV. A. Skybchyk' ${ }^{1}$ O. S. Peleshko² \\ Danylo Halytskyi Lviv National Medical University ${ }^{1}$ \\ Central Town Hospital of Chervonohrad Town Counsil2
}

SUMMARY. The relationship between high blood pressure (BP) and cognitive impairment has attracted particular attention in recent decades. Nowadays, there are not enough data about the effect of diurnal blood pressure profile on cognitive function.

The aim of the study - to analyse the relationship between circadian BP pattern and cognitive function in patients with hypertensive disease.

Material and Methods. To this purpose, we selected 45 hypertensives with arterial hypertension 2-3 degrees (the

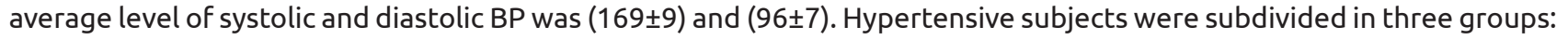
dippers ( $n=20)$, non-dippers $(n=14)$, and hyper-dippers $(n=11)$ according to a nocturnal fall of blood pressure. Neuropsychological examination was carried out by Mini-Mental State Examination (MMSE).

Results. It was found that $70 \%$ of dippers had cognitive disorders, among nondippers cognitive disorders were detected in $93 \%$ and among hyper-dippers - in $100 \%$. Light cognitive impairments predominated in structure among dippers and nondippers, whereas mild cognitive impairments predominated among hyper-dippers. Significant differences between hyper-dippers and dippers were found in the MMSE scores ((25.9 \pm 1.3$)$ and $(26.8 \pm 2.7), p<0.05)$.

Conclusions. Cognitive disorders were found in three groups of hypertension patients, however, hyper-dipping pattern was associated with lower cognitive function.

KEY WORDS: hypertension; cognitive impairment; diurnal blood pressure profile

Отримано 01.02.2019 